\title{
Faktor-Faktor yang Mempengaruhi Motivasi Wanita Untuk Berwirausaha di Pekanbaru
}

\author{
NURUL SUKRIANI \\ Sekolah Tinggi Ilmu Ekonomi Persada Bunda \\ Jl. Diponegoro No. 43 Pekanbaru-Riau, Telp. (0761) - 40218 \\ E-mail : nurulhijab85@gmail.com
}

\begin{abstract}
This study aims to determine the motivation of women to become entrepreneurs in Pekanbaru with the limitation of the problem only focused on culinary home entrepreneurs, using the variables of independence, capital, emotional, and education to analyze their effects on entrepreneurial motivation. The population in this study were all female entrepreneurs engaged in home-based culinary businesses in Pekanbaru City whose numbers were not known with certainty, for populations whose numbers were unknown, the sampling in this study used the Wibisono formula and obtained a total sample of 97 person. Data were collected by questionnaire method, namely by giving a list of questions directly to the respondents. The data analysis technique used is multiple linear regression analysis which is operated through the SPSS 16 for Windows program. The results showed that simultaneous independence, capital, emotional and educational variables significantly influenced the motivation of women to become entrepreneurs in Pekanbaru. While partially for the independence and emotional variables do not directly affect the motivation of women to entrepreneurship in Pekanbaru.
\end{abstract}

Keywords: Entrepreneur Motivation, Independence, Capital, Emotional, Education

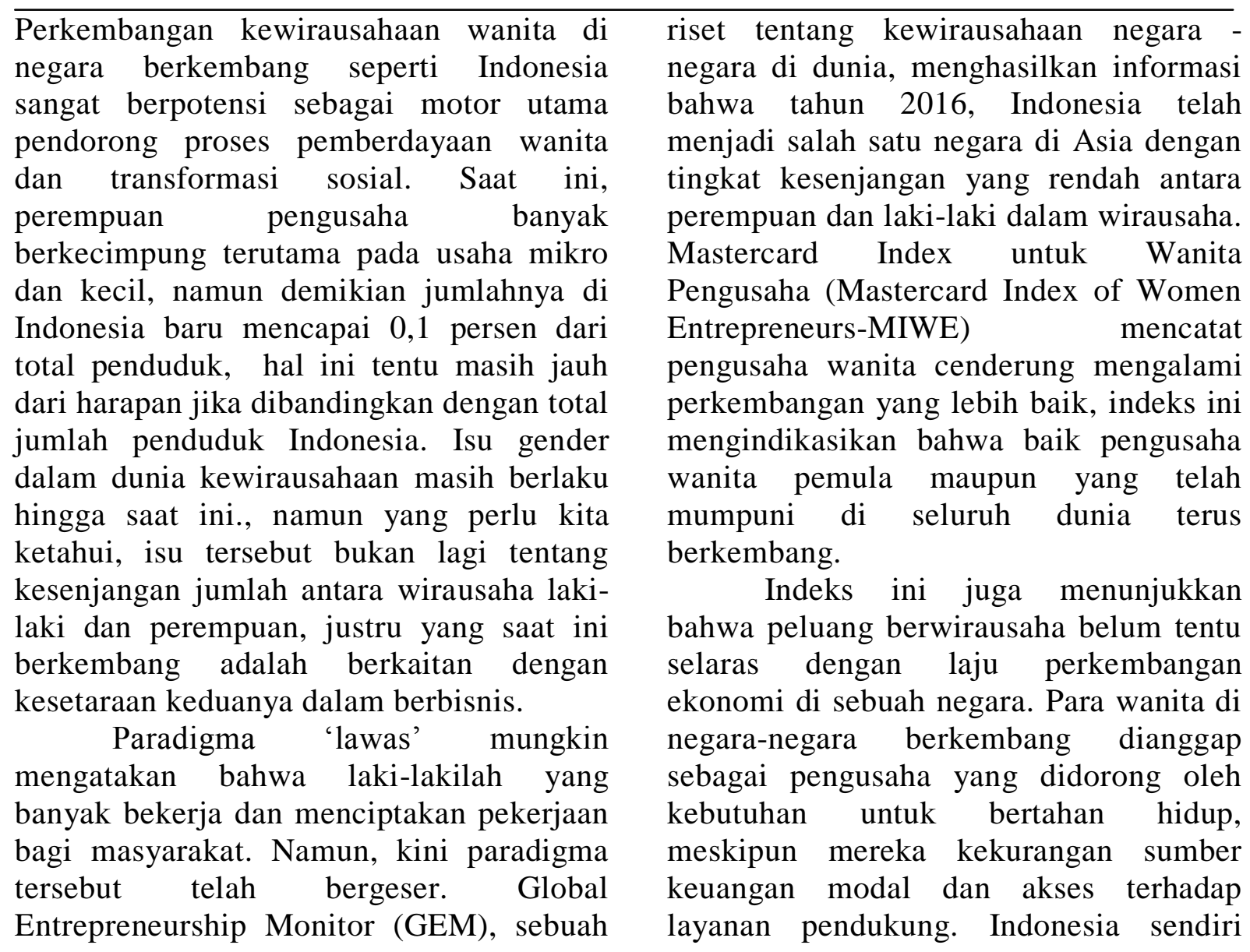


dalam hasil survey tersebut menempati posisi ke-30 sebagai negara yang memiliki peluang bagi wanita untuk berwirausaha. Sebanyak 62,4 persen wanita di Indonesia awalnya menjalankan usahanya karena terdorong oleh kebutuhan (Merdeka.com, 2018). Kondisi secara umum yang terjadi pada wanita Indonesia, yang pada langkah awal terjun ke dunia usaha adalah untuk membantu ekonomi keluarga ini, juga terjadi di Kota Pekanbaru. Pekanbaru adalah Ibu Kota dari Provinsi Riau, sebagai salah satu ibu kota metropolitan di Indonesia Pekanbaru menyimpan banyak potensi bisnis yang bisa di andalkan, salah satu potensi usaha yang sangat potensial adalah bergerak di bidang kuliner. Semakin sulit nya ruang gerak wanita misalnya saat mereka sudah menikah, dan semakin banyaknya tingkat pengangguran khususnya di kota Pekanbaru, di tambah dengan biaya - biaya hidup yang semakin meningkat, membuat para wanita sekarang ini untuk semakin kreatif dan inovatif untuk berwirusaha.

Perempuan memiliki peranan besar dalam pertumbuhan ekonomi nasional. Berdasarkan hasil penelitian International Finance Corporatin (IFC) di tahun 2015, kontribusi pelaku usaha perempuan terhadap Produk Domestik Bruto (PDB) Indonesia mencapai 9,1 persen. Deputi Gubernur Bank Indonesia (BI) Rosmaya Hadi mengatakan, peranan perempuan terhadap kegiatan ekspor juga memiliki kontribusi meskipun kecil, yakni di bawah 5 persen. "Pengusaha perempuan umumnya merupakan pengusaha kecil dan bergerak di sektor informal, sehingga turnover penjualannya lebih rendah dibanding pengusaha laki-Iaki," ujar Rosmaya dalam event seminar internasional di Jakarta Convention Center (JCC) (iNews.id, 2018). Saat ini, penduduk perempuan Indonesia lebih banyak bekerja pada sektor informal yang mencapai 40.2 persen dari total 60,9 juta orang pekerja sektor informal. Sektor informal merupakan bagian penting dari kehidupan ekonomi, sosial, dan politik di sebagian besar negara berkembang, serta beberapa negara maju.

Berdasarkan hasil observasi penelitian ini, di Kota Pekanbaru sendiri para wanita lebih banyak memilih usaha kuliner rumahan pada awal mereka mulai berwirauwsaha, hal ini dikarenakan berwirausaha dalam bidang usaha kuliner rumahan tidaklah memerlukan modal yang besar dan tempat usaha yang besar pada awal pendirian usahanya, banyak para wanita yang hanya memulai usaha kuliner tersebut dari dapur mereka sendiri. Pemilihan bisnis usaha kuliner rumahan ini memang langkah yang tepat dalam memulai usaha, hal ini karena hambatan untuk masuk dalam usaha kuliner rumahan tidak lah sesulit jika dibandingkan bisnis - bisnis rumahan lainnya seperti bisnis pakaian atau kerajinan. Fakta bahwa begitu marak nya pertumbuhan usaha kuliner rumahan yang sebagian besar di dominasi oleh kaum wanita sebagaimana yang digambarkan diatas, mengindikasikan adanya faktor faktor yang memotivasi mereka untuk memutuskan terjun ke dunia wirausaha dan menjadi entrepreneur. Namun demikan dari berbagai studi empiris terdahuluyang telah dilakukan oleh peneliti yang lain, penulis menjumpai bahwa belum banyak kajian dilakukan secara spesifik mengenai motivasi wanita dalam berwirausaha di bidang usaha kuliner rumahan khususnya dalam konteks di Kota Pekanbaru.

Atkinson (2011) mengusulkan ada tiga macam dorongan mendasar dalam diri orang yang termotivasi : Kebutuhan untuk berprestasi (need for achievement), adalah dorongan dalam diri seseorang untuk mengatasi segala tantangan dan hambatan dalam mencapai tujuan. Entrepreneur yang berorientasi dan bekerja keras apabila mereka memandang bahwa mereka akan memperoleh kebanggaan pribadi atas upaya mereka, apabila hanya terdapat sedikit resiko gagal, dan apabila mereka mendapat balikan spesifik tentang prestasi diwaktu 
lalu. Kebutuhan kekuatan (need for power), dorongan untuk mempengaruhi orangorang dan mengubah situasi. Orang-orang yang bermotivasi kekuasaan ingin menimbulkan dampak dan mau memikul resiko untuk melakukan hal itu. Kebutuhan untuk berafiliasi (need for affiliation), dorongan untuk berhubungan dengan orang-orang atas dasar social. Orang-orang yang bermotivasi afiliasi bekerja lebih baik apabila mereka dipuji karena sikap dan kerja sama mereka yang menyenangkan.

Keseimbangan antara ketiga dorongan ini bervariasi dari orang yang satu ke orang yang lain. Misalnya, seseorang mungkin mempunyai kebutuhan untuk berafiliasi yang kuat, sementara orang lain mempunyai kebutuhan berprestasi yang kuat.

Kewirausahaan (entrepreneurship) diartikan orang yang menciptakan kerja bagi orang lain dengan cara mendirikan, mengembangkan, dan melembagakan perusahaan miliknya sendiri dan bersedia mengambil resiko pribadi dalam menentukan peluang berusaha. Menurut Kasmir (2011) secara sederhana wirausahawan (entrepreneur) adalah orang yang berjiwa berani mengambil risiko untuk membuka usaha dalam berbagai kesempatan. Berjiwa berani mengambil risiko artinya bermental mandiri dan berani memulai usaha, tanpa diliputi rasa takut cemas sekalipun dalam kondisi tidak pasti. Peter F. Drucker dalam Kasmir (2011) menyatakan bahwa kewirausahaan adalah kemampuan menciptakan sesuatu yang baru dan berbeda. Sedangkan menurut Swasono dalam Suryana (2013) wirausaha adalah pengusaha, tetapi tidak semua pengusaha adalah wirausaha. Wirausaha adalah pelapor dalam bisnis, inovator, penanggung risiko yang mempunyai visi ke depan dan memiliki keunggulan dalam prestasi di bidang usaha.

Dari definisi dari beberapa ahli di atas, dapat disimpulkan bahwa kewirausahaan adalah suatu proses dari sikap yang aktif, ide-ide, kreativitas, dan inovasi guna meningkatkan kualitas hidup dan nilai tambah pada masyarakat, sedangkan wirausahawan adalah seseorang yang memiliki kreativitas, mandiri dan berani mengambil risiko untuk mencapai nilai komersial yang paling tinggi dengan memanfaatkan sumber daya yang ada. Berikut ini adalah manfaat adanya entrepreneur, antara lain (Buchari Alma, 2009):

a. Menambah daya tampung tenaga kerja, sehingga dapat mengurangi pengangguran.

b. Sebagai generator pembangunan lingkungan, bidang produksi, distribusi, kesejahteraan, dan sebagainya.

c. Menjadi contoh bagi anggota masyarakat lain, sebagai pribadi unggul yang patut dicontoh, diteladani, karena seorang entrepreneur itu adalah terpuji, jujur, berani, hidup tidak merugikan orang lain.

d. Selalu menghormati hukum dan peraturan yang berlaku, berusaha selalu menjaga dan membangun lingkungan.

e. Berusaha memberi bantuan kepada orang lain dan pembangunan social sesuai dengan kemampuannya.

f. Berusaha mendidik karyawan menjadi orang mandiri, disiplin, jujur dan tekun menghadapi pekerjaan.

g. Memberi contoh bagaimana kita harus bekerja keras, tetapi tidak melupakan perintah-perintah agama.

h. Hidup secara efisien, tidak berfoya-foya dan tidak boros.

i. Memelihara keserasian lingkungan, baik dalam pergaulan maupun kebersihan lingkungan.

Melihat manfaat adanya entrepreneur diatas, maka terdapat dua darma bakti para entrepreneur terhadap pembangunan bangsa, yaitu: Sebagai entrepreneur, memberikan darma baktinya melancarkan proses produksi, distribusi dan konsumsi. Wirausaha 
mengatasi kesulitan lapangan kerja, meningkatkan pendapatan masyarakat; Sebagai pejuang bangsa dalam bidang ekonomi, meningkatkan ketahanan nasional, mengurangi ketergantungan pada bangsa lain.

$$
\text { Menurut Kasmir }
$$

pengetahuan kewirausahaan adalah dasar dari sumber daya kewirausahaan yang terdapat di dalam diri individu. Seorang wirausaha tidak akan berhasil apabila tidak memiliki pengetahuan, kemampuan, dan kemauan. Ada kemauan tetapi tidak memiliki pengetahuan dan kemampuan tidak akan membuat seseorang menjadi wirausaha yang sukses. Sebaliknya, menurut Suryana (2013) memiliki pengetahuan dan kemampuan tetapi tidak disertai dengan kemauan, tidak akan membuat wirausaha mencapai kesuksesan. Beberapa pengetahuan yang harus dimiliki oleh para wirausaha adalah: 1). Pengetahuan mengenai usaha yang akan dimasuki/dirintis dan lingkungan usaha yang ada. 2). Pengetahuan tentang peran dan tanggung jawab. 3). Pengetahuan tentang manajemen dan organisasi bisnis.

$$
\text { Menurut (Zimmerer dan }
$$

Scarborough, 2008 : 26), jika diperhatikan entrepneur yang ada di masyarakat sekarang ini, maka di jumpai berbagai macam profil, yaitu: 1). Young Entrepreneur - Orang-orang muda mengambil bagian dalam memulai bisnis. Didorong kekecewaan akan prospek pada perusahaan pemerintah dan keinginan untuk memiliki peluang menentukan nasib mereka sendiri, banyak generasi muda lebih memilih kewirausahaan sebagai jalur karir mereka. 2). Women Entrepreneur - Banyak wanita yang terjun ke dalam bidang bisnis. Alasan mereka menekuni bidang bisnis ini didorong oleh faktor-faktor antara lain ingin memperlihatkan kemampuan prestasinya, membantu ekonomi keluarga, frustasi terhadap pekerjaan sebelumnya. 3). Minority Entreprenuer - Kaum minoritas di Negara kita Indonesia kurang memiliki kesempatan kerja dilapangan pemerintahan sebagaimana layaknya warga negara pada umumnya. Oleh sebab itu, mereka berusaha menekuni kegiatan bisnis dalam kehidupan sehari-hari. Demikian pula para perantau dari daerah tertentu yang menjadi kelompok minoritas pada suatu daerah, mereka juga berniat mengembangkan bisnis. Kegiatan bisnis ini semakin lama semakin maju, dan arena mereka membentuk organisasi minoritas di kota-kota tertentu. 4). Immigrant Entrepreneur - Kaum pedagang yang memasuki suatu daerah biasanya sulit untuk memperoleh pekerjaan formal. Oleh sebab itu, mereka lebih leluasa terjun dalam pekerjaan yang bersikap non formal yang dimulai dari berdagang kecilkecilan sampai berkembang menjadi perdagangan tingkat menengah. 5). Part Time Entrepreneur - Memulai bisnis dalam mengisi waktu lowong merupakan pintu gerbang untuk berkembang menjadi usaha besar . bekerja paruh waktu tidak mengorbankan pekerjaan dibidang lain misalnya seorang pegawai pada sebuah kantor bermaksud mengembangkan hobinya untuk berdagang atau mengembangkan hobi yang menarik. Hobi ini akhirnya mendapat keuntungan yang lumayan. Ada kalanya orang ini beralih profesi, dan berhenti menjadi pegawai dan beralih bisnis yang merupakan hobinya. 6). Home-Based entrepreneur - Ada ibuibu rumah tangga yang memulai kegiatan bisnisnya dari rumah tangga misalnya ibuibu yang pandai membuat kue dan aneka masakan, mengirim kue-kue ke toko eceran di tempatnya. Akhirnya usaha makin lama makin maju. Usaha catering banyak dimulai dari rumah tangga yang bisa masak, kemudian usaha ini berkembang melayani pesanan untuk pesta. 7). Family-owned business Sebuah keluarga dapat membuka berbagai jenis cabang dan usaha. Mungkin saja usaha keluarga ini dimulai lebih dahulu oleh orang tua. setelah usaha orang tua ini maju dibuka cabang baru dan dikelola ibu. Kedua perusahaan ini maju dan membuka beberapa cabang lain mungkin jenis usahanya berbeda atau lokasinya berbeda. 
Masing-masing usahanya ini bisa dikembangkan atau dipimpin oleh anakanak mereka. Dalam keadaan sulitnya lapangan pekerjaan pada saat ini maka kegiatan ini perlu dikembangkan. 8). Corpreneurs - Corpreneurs adalah pasangan wirausaha yang bekerja sama - sama sebagai pemilik bersama dari usaha mereka. Corpreneurs di buat dengan cara menciptakan pekerjaan yang didasarkan atas keahlian masing-masing orang. Orangorang yang ahli di bidang ini diangkat menjadi penanggung jawab divisi tertentu dari bisnis-bisnis yang sudah ada.

Menurut (Zimmerer dan Scarborough, 2008:27), meskipun telah diperjuangkan selama bertahun-tahun secara legislatif, wanita tetap mengalami diskriminasi ditempat kerja. Meskipun demikian, bisnis kecil telah menjadi pelopor dalam menawarkan peluang di bidang ekonomi baik kewirausahaan maupun kekerjaan. Dikatakan bahwa "Kewirausahaan telah bersifat unisex seperti celana jeans, dimana disini wanita dapat mengembangkan impian maupun harapan terbesarnya". Semakin banyak wanita yang menyadari bahwa menjadi wirausaha adalah cara terbaik untuk menembus dominasi laki-laki yang menghambat peningkatan karir waktu ke puncak organisasi melalui bisnis mereka sendiri.

Faktanya, wanita yang membuka bisnis 2,4 kali lebih banyak daripada pria. Meskipun bisnis yang di buka oleh wanita cenderung lebih kecil dari yang di buka pria, tetapi dampaknya sama sekali tidak kecil. Perusahaan-perusahaan yang dimiliki wanita memperkerjakan lebih dari 15,5 juta karyawan atau 35 persen lebih banyak dari semua karyawan fortune 500 di seluruh dunia. Wanita memiliki 36 persen dari semua bisnis. Meskipun bisnis mereka cenderung tumbuh lebih lambat daripada perusahaan yang dimiliki pria, wanita pemilik bisnis memiliki daya hidup lebih tinggi daripada keseluruhan bisnis. Meskipun 72 persen bisnis yang dimiliki wanita terpusat dalam bidang eceran dan jasa, wirausahawan wanita berkembang dalam industri yang sebelumnya dikuasai oleh laki-laki, seperti pabrik, konstruksi, transportasi dan pertanian. Studi mengenai motivasi berwirausaha telah banyak dilakukan dimana hasil penelitian menunjukkan bahwa faktor yang mempengaruhi motivasi berwirausaha sangat beragam. Kumar et all. (2003) menemukan bahwa motivasi berwirausaha dari partisipan yang terlibat dalam penelitian mereka dapat dikelompokkan menjadi dua yaitu motivasi internal dan eksternal. Yang termasuk di dalam motivasi internal antara lain: keinginan untuk melakukan sesuatu yang baru; tingkat pendidikan partisipan; latar belakang; jumlah tahun pengalaman bekerja; dan latar belakang pekerjaan partisipan. Sedangkan motivasi eksternal meliputi: dukungan dan bantuan pemerintah; ketersediaan faktor produksi; serta permintaan produk yang menjanjikan. Studi mengenai motivasi berwirausaha juga dilakukan dengan mengadopsi teori motivasi push and pull factors untuk menggali faktor-faktor yang memotivasi individu untuk memulai sebuah usaha bisnis baru. Gilad dan Levine (1986) sebagaimana dikutip dalam Zimmerer dan Scarborough (2008), yang pada awalnya mengkaji motivasi berwirausaha dari teori daya dorong ( $p u s h$ theory) dan teori daya tarik (push theory).

Menurut Anoraga dalam penelitian yang dilakukan Segarahati dan Walmiaty (2015), Faktor-faktor yang mendorong wanita memilih berwirausaha antara lain :

1. Faktor kemandirian - Sebagai seorang wanita, ada kalanya wanita ini dapat berdiri sendiri tanpa bantuan orang lain. Hal ini karena wanita ingin menunjukkan jika tanpa laki-laki dia dapat bertahan hidup dengaa keahlian yang dia punya yang direalisasikan menjadi suatu usaha yang dapat menghasilkan untuk pemenuhan kebutuhan hidupnya. Walaupun tidak memungkiri keahlian laki-laki dalam bekerja, tetapi wanita juga ingin 
menunjukkan bahwa mereka dapat mengerjakan apapun yang dikerjakan pria.

2. Faktor modal - Dalam pembuatan usaha maka wanita biasanya melihat berapa modal yang mereka punya untuk membuat suatu usaha, biasanya semakin banyak modal yang mereka miliki untuk pembuatan suatu usaha maka semakin terencana dan matanglah pemikiran untuk rencana pembuatan usaha ini.

3. Faktor emosional - Faktor emosional yang dimiliki wanita, dapat mempengaruhi dirinnyauntuk melakukan sesuatu yang berguna baginya maupun keluarga. Hal ini karena dalam diri seorang wanita memiliki keinginan untuk dapat berdiri sendiri maupun untuk bisa mempraktekkan teori-teori yang diikutinya melalui pendidikan formal maupun informal yang diinginkannya. Selain itu wanita juga mempunyai keinginan untuk membantu keuangan keluarga yaitu dengan membuka usaha.

4. Faktor pendidikan - Faktor pendidikan dapat menjadi salah satu faktor yang memotivasi wanita untuk berwirausaha karena banyak wanita-wanita yang tidak dapat pendidikan informal seperti kursus-kursus yang dapat mengasah keterampilan mereka, sehingga ilmu yang mereka dapat di pendidikan informal dapat mereka jadikan modal untuk membuat suatu usaha. Begitu bagi wanita-wanita yang memiliki pendidikan tinggi, mereka akan berpikir kembali untuk menggunakan ijazah perguruan tinggi mereka untuk bekerja dikantorkantor yang mempunyai waktu bekerja "from eight to five" atau dari jam delapan hingga jam 5 sore, ini dikarenakan mereka yang tidak dapat mereka lakukan jika mereka bekerja di kantor-kantor dari pagi hingga sore.

\section{METODE}

Penelitian ini dilakukan di kota Pekanbaru, Penulis memilih Kota Pekanbaru sebagai lokasi penelitian dikarenakan selain mempertimbangkan teori mengenai efisiensi waktu, biaya dan tenaga, kota Pekanbaru merupakan sebuah kota yang cukup padat, sekaligus ibu kota Provinsi Riau, sehingga dapat merepresentatif untuk kebutuhan penelitian ini. Adapun waktu penelitian yang telah dilakukan yaitu berkisar selama enam bulan, dari bulan Februari hingga bulan Juli.

Populasi merupakan wilayah generalisasi yang terdiri atas obyek dan subyek yang memiliki karakteristik tertentu dan mempunyai kesempatan yang sama, untuk dipilih menjadi anggota sampel (Umar, 2012:77). Populasi dalam penelitian ini adalah seluruh pelaku usaha wanita yang bergerak di bidang usaha kuliner rumahan di Kota Pekanbaru yang jumlahnya tidak diketahui dengan pasti.

Menurut Sugiyono sampel adalah bagian dari jumlah dan karakteristik yang dimiliki oleh populasi tersebut. Pada penelitian ini jumlah populasi yang ada sangat banyak sehingga sulit diketahui jumlahnya, sehingga teknik pengambilan sampel yang digunakan adalah teknik non-probability sampling, yaitu teknik pengambilan sampel dengan tidak memberikan kesempatan yang sama bagi setiap unsur atau anggota populasi untuk dipilih menjadi sampel dan dengan metode purposive sampling yaitu teknik pengambilan sampel sumber data dengan pertimbangan atau kriteria tertentu, Sugiyono (2014:9).

Menurut Riduwan dan Akdon (2010:66) untuk populasi yang tidak diketahui jumlahnya, penelitian dapat menggunakan rumus Wibisono (2003) untuk mengetahui jumlah sampel yang digunakan. Berdasarakan uraian diatas jumlah sampel yang akan diambil dalam penelitian ini adalah sebanyak 97 responden. Metode pengambilan menggunakan purposive sampling yaitu teknik pengambilan sampel sumber data dengan pertimbangan atau kriteria tertentu. Adapun kriteria yang ditetapkan dalam penelitian ini adalah (1) pelanggan minimal 
berusia 18 tahun (2) telah memiliki usaha minimal 1 tahun.

\section{Uji Validitas}

Uji validitas merupakan suatu alat ukur tes dalam kuesioner, Sunyoto (2014). Pengujian validitas dengan menggunakan $\alpha=$ $0,05(5 \%)$ diketahui $r_{\text {hitung }}>r_{\text {tabel }}$. Dan apabila $\mathrm{r}_{\text {hitung }}<\mathrm{r}_{\text {tabel }}$ maka status kuesioner atau angket dinyatakan gugur. Dalam penelitian ini, pengujian validitas dilakukan dengan menggunakan bantuan SPSS 16.

\section{Uji Reliabilitas}

Menurut Sugiyono (2008 : 172), uji reliabilitas digunakan untuk mengetahui apakah alat pengumpul data menunjukkan tingkat ketepatan, tingkat keakuratan, kestabilan atau konsisten dalam mengungkapkan gejala tertentu. Syarat dalam uji reliabilitas ini adalah, jika nilai koefisien cronbach's alpha besar dari 0,6 maka instrumen penelitian tersebut dikatakan reliable.

\section{Uji Hipotesis}

Pengujian hipotesis uji simultan (uji F), yaitu untuk melihat signifikansi secara bersama - sama variabel bebas terhadap variabel terikat. 2. Uji parsial (uji t) untuk melihat pengaruh secara sendiri -sendiri masing-masing variabel bebasnya terhadap variabel terikat.

\section{Uji Koefisien Determinasi}

Uji koefisien determinasi digunakan untuk mengetahui persentase sumbangan pengaruh variabel independen $(\mathrm{X})$, terhadap variabel dependen (Y). Koefisien ini menunjukkan seberapa besar persentase variasi variabel independen yang digunakan dalam model dan mampu menjelaskan variasi variabel dependen.

\section{HASIL}

Dari hasil penelitian yang dilakukan dan sebelumnya dilakukan uji instrumen dan kualitas data. Uji validitas dilakukan dengan membandingkan nilai $r$ hitung dengan $r$ tabel pada taraf signifikansi $5 \%$. Jika $r$ hitung $>r$ tabel maka alat ukur yang digunakan dinyatakan valid dan sebaliknya. Nilai $\mathrm{r}$ tabel dapat diperoleh dengan persamaan $\mathrm{N}$ $2=97-2=95$ sehingga diperoleh nilai $\mathrm{r}$ tabel sebesar 0,199, dan nilai $r$ hitung diperoleh dengan metode Corrected ItemTotal Correlation, berdasarkan uji validitas yang penulis lakukan dalam penelitian ini maka di peroleh nilai korelasi terendah sebesar 0,303, maka dengan demikian seluruh item yang di uji dalam penelitian ini adalah valid karena memiliki $\mathrm{r}$ tabel > 0,199, sehingga dapat digunakan untuk analisis tahapan selanjutnya.

Menurut Umar (2008:56), uji reliabilitas untuk alternatif jawaban lebih dari dua menggunakan uji cronbach's alpha, yang nilainya akan dibandingkan dengan nilai koefisien reliabilitas minimal yang dapat diterima. Uji reliabilitas digunakan untuk mengukur tingkat kehandalan suatu kuesioner yang digunakan sebagai indikator dari variabel. Jika koefisien alpha yang dihasilkan $\geq 0,60$, maka indikator tersebut dikatakan reliabel atau handal (dapat dipercaya). Dari hasil pengujian reliabelitas, diketahui nilai reliabilitas seluruh variabel dalam penelitian ini adalah $\geq 0,60$. Artinya bahwa alat ukur yang digunakan dalam penelitian ini reliabel atau handal (dapat dipercaya). Dengan demikian dapat disimpulkan bahwa item-item untuk keenam variabel sudah baik dan layak untuk dilakukan penelitian selanjutnya.

Dari pengolahan data diketahui kedua variabel bebas dalam penelitian ini memilki VIF < 10, sehingga dapat dikatakan tidak terdapat gejala multikolinearitas antara variabel bebas dalam penelitian ini. Artinya antara kedua variabel bebas yang diteliti tidak saling berhubungan sehingga tepat digunakan sebagai variabel bebas dalam model.

Dari pengolahan data diperoleh hasil dari keseluruhan variable $\mathrm{X}$ yaitu Kemandirian, Modal, Emosional, dan pendidikan dalam penelitian ini, memiliki nilai koefesien spearman $>0,6$, sehingga dapat disimpulkan tidak terdapat gejala 
heteroskedastisitas antara variabel dalam penelitian ini.

Dari pengolahan data diperoleh hasil bahwa nilai signifikansi KolmogorovSmirnov dalam penelitian ini di peroleh sebesar 0,112, 0,075, 0,064, dan 0, 062, dengan demikian seluruh nilai signifikansi yang diperoleh $>0,05$, sehingga dapat disimpulkan bahwa seluruh variabel dalam penelitian ini memenuhi syarat uji normalitas.

Berdasarkan hasil pengolahan data variabel kualitas pelayanan (X) dan kepuasan pelanggan (Y) yang menggunakan program SPSS (Statistics Product and Service Solution), maka diperoleh nilai konstanta dan koefisien regresi linier berganda yang dapat dilihat pada tabel sebagai berikut :

Tabel 1: Hasil Analisis Regresi Linier Berganda

Coefficients $^{\mathbf{a}}$

\begin{tabular}{|c|c|c|c|c|c|}
\hline \multirow[b]{2}{*}{ Model } & \multicolumn{2}{|c|}{$\begin{array}{l}\text { Unstandardized } \\
\text { Coefficients }\end{array}$} & \multirow{2}{*}{$\begin{array}{l}\text { Standardiz } \\
\text { ed } \\
\text { Coefficient } \\
\text { s } \\
\text { Beta } \\
\end{array}$} & \multirow[b]{2}{*}{$\mathrm{T}$} & \multirow[b]{2}{*}{ Sig. } \\
\hline & B & Std. Error & & & \\
\hline $\begin{array}{ll}1 \quad \text { (Constan } \\
\text { t) }\end{array}$ & .212 & 1.189 & & .178 & .859 \\
\hline $\mathrm{X} 1$ & .231 & .125 & .210 & 1.849 & .068 \\
\hline $\mathrm{X} 2$ & .450 & .132 & .275 & 3.409 & .001 \\
\hline $\mathrm{X} 3$ & .015 & .112 & .010 & .138 & .890 \\
\hline $\mathrm{X} 4$ & .448 & .103 & .459 & 4.339 & .000 \\
\hline
\end{tabular}

Adapun model persamaan regresi linier berganda yang diperoleh adalah sebagai berikut:

$\mathrm{Y}=0,212+0,231 \mathrm{X}_{1}+0,450 \mathrm{X}_{2}+0,015 \mathrm{X}_{3}$ $+0,448 \mathrm{X}_{4}$

Dari hasil diatas dapat dijelaskan yaitu:

a. Nilai konstanta (a) sebesar 0,212, Artinya adalah peningkatan Motivasi Berwirausaha jika variable lain dianggap konstan, maka Motivasi Berwirausaha bernilai 0,212 .

b. Nilai koefisien regresi variabel Kemandirian sebesar 0,231. Artinya adalah bahwa setiap peningkatan Kemandirian sebesar 1 (satu) satuan maka akan meningkatkan Motivasi
Berwirausaha sebesar 0,231 , dengan asumsi variabel lain tetap.

c. Nilai koefisien regresi variabel Modal sebesar 0,450. Artinya adalah bahwa setiap peningkatan Modal sebesar 1 (satu) satuan maka akan meningkatkan Motivasi Berwirausaha sebesar 0,450, dengan asumsi variabel lain tetap.

d. Nilai koefisien regresi variabel Emosional sebesar 0,015. Artinya adalah bahwa setiap peningkatan Emosional sebesar 1 (satu) satuan maka akan meningkatkan Motivasi Berwirausaha sebesar 0,015, dengan asumsi variabel lain tetap.

e. Nilai koefisien regresi variabel Pendidikan sebesar 0,448. Artinya adalah bahwa setiap peningkatan Pendidikan sebesar 1 (satu) satuan maka akan meningkatkan Motivasi Berwirausaha sebesar 0,448, dengan asumsi variabel lain tetap.

Hasil Pengujian Hipotesis Secara Simultan Tabel Uji Hipotesis Secara Simultan

Uji $F$ digunakan untuk mengetahui besarnya pengaruh signifikan variabel bebas (X) secara simultan atau bersamasama terhadap variabel terikat (Y).

Tabel 2: Uji Hipotesis Secara Simultan ANOVA $^{\text {b }}$

\begin{tabular}{|c|c|c|c|c|c|c|}
\hline \multicolumn{2}{|c|}{ Model } & $\begin{array}{l}\text { Sum of } \\
\text { Squares }\end{array}$ & df & $\begin{array}{l}\text { Mean } \\
\text { Square }\end{array}$ & $F$ & Sig. \\
\hline 1 & $\begin{array}{l}\text { Regres } \\
\text { sion }\end{array}$ & 2020.464 & 4 & 505.116 & 77.934 & $.000^{\mathrm{a}}$ \\
\hline & $\begin{array}{l}\text { Residu } \\
\text { al }\end{array}$ & 596.279 & 92 & 6.481 & & \\
\hline & Total & 2616.742 & 96 & & & \\
\hline
\end{tabular}

Diketahui F hitung sebesar 77.934 dengan signifikansi $(0,000), \mathrm{F}$ tabel dapat diperoleh sebagai berikut: $\mathrm{F}$ tabel $=97-5-$ 1; $5, \mathrm{~F}$ tabel $=91 ;($ Kolom ke 5 di tabel $\mathrm{F})$ $=2,31$. Berdasarkan hasil pengolahan data diperoleh nilai $F_{\text {hitung }}(143,553)>F_{\text {tabel }}$ $(2,31)$ dengan Sig. $(0,000)<0,05$. Artinya adalah bahwa variabel independen 
Kemandirian, Modal, Emosional, Pendidikan secara bersama-sama berpengaruh signifikan terhadap variabel independen (Motivasi Berwirausaha). Maka $\mathrm{H}_{0}$ ditolak dan $\mathrm{H}_{1}$ diterima.

\section{Hasil Pengujian Hipotesis Secara Parsial}

Uji $\mathrm{t}$ dilakukan untuk mengetahui pengaruh variabel bebas $X$ terhadap variabel terikat $Y$. Pengujian dilakukan dengan membandingkan $t_{\text {hitung }}$ dengan $t_{\text {tabel. }}$. Untuk mencari t tabel pada alpha $5 \%$ dan degree of freedom (df) dengan rumus sebagai berikut:

$\mathrm{t}$ tabel $=\mathrm{n}-\mathrm{k}-1:$ alpha/ 2

$=97-5-1: 5 \% / 2$

$=91: 0,025$

$=1,986$

Keterangan: $\mathrm{n}$ : jumlah

$\mathrm{k}$ : jumlah variabel bebas

\section{PEMBAHASAN}

Dari hasil analisis yang dilakukan maka dapat dilakukan pembahasan per variabel.

a. Kemandirian

Dari hasil pengolahan data di peroleh nilai $t_{\text {hitung }}$ lebih kecil dari $t_{\text {tabel }}(1.849)<$ $(1,986)$. Karena $\mathrm{t}$ hitung lebih kecil dari $\mathrm{t}$ tabel maka dapat dikatakan bahwa Kemandirian tidak berpengaruh terhadap Motivasi Berwirausaha.

Hal ini berbeda dengan pendapat yang disampaikan oleh Novita, N. (2016) hal ini karena dalam kondisi tertentu dan terdesak kemandirian akan muncul dan pada kondisi yang tidak terdesak maka akan tenang saja.

b. Modal

Dari hasil pengolahan data di peroleh nilai $t_{\text {hitung }}$ lebih besar dari $t_{\text {tabel }}(3.409)>$ $(1,986)$. Karena $t$ hitung lebih besar dari $t$ tabel maka dapat dikatakan bahwa Modal mempengaruhi Motivasi Berwirausaha.

Hal ini sejalan dengan hasil penelitian Rahman, F. (2017) bahwa peran modal apakah itu modal manusia ataupun modal investasi sangat mempengaruhi hasil kerja para pengelola usaha kecil.

c. Emosional

Dari hasil pengolahan data di peroleh nilai $t_{\text {hitung }}$ lebih kecil dari $\mathrm{t}_{\text {tabel }}(0,138)<$ $(1,986)$. Karena $\mathrm{t}$ hitung lebih kecil dari $\mathrm{t}$ tabel maka dapat dikatakan bahwa Emosional tidak berpengaruh terhadap Motivasi Berwirausaha.

Hal ini juga berbeda dengan pendapat Hadiyati, (2018) karena faktor emosi sangat terkait dengan situasi dan kondisi.

\section{d. Pendidikan}

Dari hasil pengolahan data di peroleh nilai $t_{\text {hitung }}$ lebih besar dari $t_{\text {tabel }}$ $(4.339)>(1,986)$. Karena nilai t hitung lebih besar dari $t$ tabel maka dapat dikatakan bahwa Pendidikan mempengaruhi Motivasi Berwirausaha.

Hal ini sejalan dengan pendapat Hadiyati, (2018) yang menyatakan bahwa pendidikan akan mendorong seseorang untuk kreatif dan inovatif.

Hasil Pengujian Koefisien Determinasi dimana nilai koefisien determinasi $\left(\mathrm{R}^{2}\right)$ sebesar 0,772. Artinya adalah variabel Motivasi Berwirausaha dapat dijelaskan oleh variabel Kemandirian, Modal, Emosional, Pendidikan sebesar $77,2 \%$ sedangkan sisanya sebesar $22,8 \%$ dipengaruhi oleh variabel lain yang tidak di teliti dalam penelitian ini.

\section{SIMPULAN}

Berdasarkan hasil penelitian Faktorfaktor yang Mempengaruhi Motivasi Wanita Untuk Berwirausaha di Pekanbaru, maka dapat ditarik kesimpulan bahwa:

1. Kemandirian tidak berpengaruh secara parsial terhadap Motivasi wanita untuk berwirausaha di Pekanbaru.

2. Modal berpengaruh secara parsial terhadap Motivasi wanita untuk berwirausaha di Pekanbaru.

3. Emosional tidak berpengaruh secara parsial terhadap Motivasi wanita untuk berwirausaha di Pekanbaru.

4. Pendidikan berpengaruh secara parsial terhadap Motivasi wanita untuk berwirausaha di Pekanbaru.

5. Kemandirian, Modal, Emosional, dan Pendidikan berpengaruh secara Simultan/Bersama-sama terhadap

p.ISSN: 2407-800X e.ISSN: 2541-4356 
Motivasi wanita untuk berwirausaha di Pekanbaru dengan koefisien determinasi yang cukup tinggi yaitu sebesar 77,2\% .

\section{DAFTAR RUJUKAN}

Anoraga, Pandji. 2004. Kewirausahaan dan Usaha Kecil. Jakarta : Penerbit Rineke Cipta.

Atkinson, R. L. 2011. Pengantar Psikologi ed. Diterjamahkan : Puspita. Jakarta: Interaksara.

Badan Pusat Statistik (BPS). http//www.bps.go.id

Basrowi. (2014). Kewirausahaan untuk Perguruan Tinggi. Bogor: Ghalia Indonesia

Alma, B. 2011. Kewirausahaan untuk Mahasiswa dan Umum.Bandung; Alfabeta.

(2013). Kewirausahaan untuk Mahasiswa dan Umum. Bandung: Alfabeta

Hadiyati, H., Suroto, B., \& Fatkhurahman, F. (2018). Pengaruh Faktor Diri Sendiri, Faktor Keluarga, Faktor Masyarakat Dan Metode Belajar Terhadap Pengembangan Jiwa Kewirausahaan Mahasiswa. Jurnal Daya Saing, 4(3), 305-311.

Kasmir. 2009. Kewirausahaan. Jakarta : Penerbit PT Raja Grafindo.

Novita, N. (2016). Analisis Kreatifitas Kelompok Masyarakat Menghadapi Kondisi Ekonomi Rumah Tangga. Jurnal Daya Saing, 2(2), 150-159.

Rahman, F. (2017). Peran Modal Manusia Dan Modal Investasi Terhadap Nilai Produksi Industri Kecil Di Kota Pekanbaru. Jurnal Benefita: Ekonomi Pembangunan, Manajemen Bisnis dan Akuntansi, 2(1), 1-9.
Rizal, Muhammad dan Dias Setianingsih. 2016. Faktor - Faktor yang Mempengaruhi Wanita Berwirausaha (Studi Kasus di Kota Langsa). Jurnal Manajemen dan Keuangan, Vol.5, No.2

Sedarmayanti, 2009, Daya Manusia dan Produktivitas Kerja, CV Mandar Maju Bandung.

(2012). Metode Penelitian Kuantitatif, Kualitatif dan R\&D. Bandung: Alfabeta

Segarahati, Enny dan Rina Walmiaty. 2015. Analisis Faktor- Faktor Yang Memotivasi Wanita Berwirausaha (Studi Kasus Pada Pengusaha Salon Kecantikan Di Kecamatan Medan Kota). ASEAN Comparative Education Research Network Conference 2015

Suryana. 2013. Kewirausahaan Kiat dan Proses Menuju Sukses. Jakarta: SALEMBA EMPAT.

Umar, Dr. Husein S.E., MBA., MM. 2008. Metode Penelitian Untuk Skripsi dan Tesis Bisnis. Edisi Kedua. Jakarta : PT Raja Grafindo Persada.

WWW.iNews.id. 2018. Pengusaha Perempuan Lebih Banyak Bekerja di Sektor Informal

WWW.Merdeka.com. 2018. Survei: 62,4 persen wanita di Indonesia memulai bisnis karena kebutuhan

Wijaya dan Tessa, 2016, Studi Eksploratif Motivasi Berwirausaha Skala Mikro Sektor Jasa Makanan di Surabaya, KINERJA, Volume 20, No.2

Zimmerer, Thomas dan Norman $M$. Scarborough. 2008. Kewirausahaan dan Manajemen Usaha Kecil. Jakarta : Penerbit Salemba Empat. 